\title{
Biological effectiveness of organic and inorganic products for the management of Maconellicoccus hirsutus green in soursop crop
}

\author{
Therola CALIFA-ESTWICK ${ }^{1 *}$ (D), Agustín ROBLES-BERMÚDEZ ${ }^{1}$, Octavio Jhonathan-Cambero CAMPOS ${ }^{1}$, \\ Gregorio LUNA-ESQUIVEL ${ }^{1}$, Néstor ISIORDIA-AQUINO ${ }^{1}$
}

\begin{abstract}
The pink mealybug Maconellicoccus hirsutus Green is a pest of economic importance in various crops around the world. The objective was to determine the biological effectiveness of organic and inorganic products for the management of $M$. hirsutus in the soursop crop. The experiment was carried out in the communities of "Lima de Abajo" and "El Capomo", in the municipality of Compostela, Nayarit, Mexico, during the period from September to November 2018 and from July to August 2019. The treatments were Ara3, Inter-a-ch-c, Evolution, a complex of plant extracts (Capsicum chinense + Allium sativum + Allium cepa + Artemisia absinthium), Mos Blanc ${ }^{\varpi}$ (Imidacloprid), farmers' control (Detergent Blanca Nieves ${ }^{\varpi}+$ Sodium Hypochlorite Cloralex ${ }^{\circledast}$ ) and the absolute control (Water). The nymphs and adult females of $M$. hirsutus were counted after each application, in young shoots. The results showed that in "Lima de Abajo", Ara 3 registered the highest percentage of suppression after 28 days. In "El Capomo", Imidacloprid recorded the greatest suppression after 28 days of application. In both communities, the treatments Ara 3, Evolution and Imidacloprid registered the least number of living individuals. The results indicated that Ara 3 and Evolution were the most promising alternatives in the management against $M$. hirsutus in the crop.
\end{abstract}

Keywords: Nayarit; suppression; Ara 3; evolution; pink mealybug.

Practical Application: Management of mealybug population using organic and inorganic products.

\section{Introduction}

Soursop (Annona muricata L.) is the most important species in the Annonaceae family. The main soursop producer in the world is Mexico with a production of 29,228 t, distributed in the states of Nayarit, Colima, Michoacán, Guerrero, Veracruz, Puebla, Tabasco, Jalisco and Campeche, with an area of 3,693 ha (Servicio de Información Agroalimentaria y Pesquera, 2018).

Recent advances has been made in the study of the soursop pulp which in research has been made by Amariz et al. (2018) in the use of soursop fibrous pulp as a byproducts which has been proven to have chemical properties and bioactive components that can potentially be use in food industry. Studies, by Nascimento et al. (2020) revealed that the physicochemical properties of frozen soursop pulps has shown to be a good source of essential elements to human, but was low in manganese and zinc. Findings by Guimarães et al. (2019) revealed that the use of HIUS technology induced both negative (degradation of the ascorbic acid, decrease of some minerals and production of many volatile compounds) and beneficial (an increase of phenolic content, improvement of the antioxidant and anti-hypertensive activity, reduction of undesired minerals) changes in the nutritional profile of the soursop whey beverage. However this crop has been affected by various phytosanitary problems, of which Maconellicoccus hirsutus Green is one of the main pests (Hernández et al., 2013; Cham et al., 2019). M. hirsutus is an exotic pest native to Southeast Asia whose distribution is cosmopolitan from the tropical and semi-tropical regions of the world. $M$. hirsutus was first found in Mexico in 1999, in the city of Mexicali, Baja California, later in February 2004 in the municipality of Bahía de Banderas, Nayarit, and Puerto Vallarta, Jalisco (Hernández et al., 2013).

$M$. hirsutus is a pest of economic importance not only for the damage it causes to the plant, but also for being a regulated pest. In Mexico, there are regulations at internal verification points for the mobilization of host products of $M$. hirsutus (Hernández et al., 2013). However, the main form of dispersion is through the mobilization of infested plant material (México, 2014). The global economic losses due to M. hirsutus in the Caribbean region during the period 1995-2008 were approximately USD \$ 18.3 million. For the Caribbean subregion, losses were approximately 138 million dollars (Rivero, 2007). With respect to the soursop area cultivated in Mexico, there was a sustained increase until 2006 (two years after reporting the presence of M. hirsutus in Nayarit, subsequently, there was a $26 \%$ reduction in production until 2009, this decrease was mainly associated presence and effects of $M$. hirsutus (Servicio de Información Agroalimentaria y Pesquera, 2010).

The pink mealybug affects all the phenological stages of the crop. The presence of this pest favours the development of sooty mould; due to its complex relationship and interdependence with other pests such as fruit flies and the symbiotic relationship 
that this pest establishes with ants to protect itself from their predators (Hernández et al., 2013). During the maturation of the female mealybug, it produces a waxy layer on the surface, This waxy layer is one of the factors that reduces the action of the chemical products, for this reason it is necessary to apply chemical products in certain instars where waxy layer is not present (Rivero, 2007; Kondo et al., 2010).

Another factor that constitutes a limitation in the production of fruit trees in the world is the ecological imbalance caused by improper practices of insect pest management. Annually, 2.5 million tons of pesticides are applied worldwide. Of the total pesticides applied, 20 to $30 \%$ are insecticides (Orozco et al., 1998). The greatest amount of pesticides applied in crops of high economic value such as fruit trees, only an insignificant amount of the chemical (less than $0.1 \%$ ) manages to reach the target pest (Pimentel \& Levitan, 1986). This means that more than $99.9 \%$ of the pesticide applied is lost in the environment, where it can cause adverse effects to beneficial fauna, soil, water and atmosphere pollution (Pimentel et al., 1993). Despite the indiscriminate use of pesticides, effective control over this pest is not achieved or because the insecticide applications were neither timely nor adequate (Pimentel et al., 1993).The management strategies of $M$. hirsutus consist mainly of chemical, biological and cultural control. The most commonly used method to combat pest insects, in Mexico is chemical control; however, there are no authorized pesticides for use in soursop (Comisión Federal para la Protección contra Riesgos Sanitarios, 2018). The chemical control of $M$. hirsutus is based on the use of products such as Horta 25 (diazinon); Dimetri 400 (dimethoate) and Siroco (cypermethrin), Cyrux 20\%, paraffinic oil, citroline, with detergent to reduce the damages attributed to fruits infested by M. hirsutus when populations are at low levels (Kondo et al., 2010; Hernández et al., 2013).

In various crops, up to six applications per year are made without effective control (Hernández et al., 2008). As a result of the intensive use of insecticides, the number of them capable of exercising satisfactory control is reduced every day, mainly due to the development of resistance (Riley \& King, 1994; Servín et al., 2007). An important part of chemical management is insecticide resistance management (Food and Agriculture Organization, 2012). However, various producers in Mexico use pesticides in the hope of reducing the impact of pests on their crops; information is lacking as to whether or not these chemicals are actually efficient, and the negative impact it has on nature (Hernández et al., 2008).

The use of pesticides for the control of agricultural pests, is not the only option to achieve success in production, there are alternatives that do not affect the balance of populations, nor induce the development of resistance neither displace species. Biological control is one such method. In Mexico, an integrated pest management program was created with emphasis on biological control with the release of the parasitoid Anagyrus kamali Moursi; a total of 7,024,000 individuals were released in 2011, generating a $98 \%$ reduction of the mealybug population at that period (Servicio Nacional de Sanidad, Inocuidad y Calidad Agroalimentaria, 2014).
The cultural control is also another method used which consists of the pruning or elimination of hosts that are positive for M. hirsutus in the areas under phytosanitary control. This includes the elimination of weed residues, cleaning of ridges, water distribution channels and affected agricultural production areas (Servicio Nacional de Sanidad, Inocuidad y Calidad Agroalimentaria, 2019). It is also convenient to apply a soap or oil solution before pruning foliage or fruits, in order to immobilize the immature stages and thus minimize the dispersion of M. hirsutus (Servicio Nacional de Sanidad, Inocuidad y Calidad Agroalimentaria, 2019). Therefore, the search for less harmful chemical alternatives in pest control is also a viable strategy, for this reason, the objective of this research was to determine the biological effectiveness of different organic and inorganic products for the management of $M$. hirsutus with the possibility of it being included as a sustainable pest management strategy of soursop in Nayarit, Mexico.

\section{Materials and methods}

Two experiments were carried out on three year old soursop orchards in a vegetative stage, with trees 5 to $8 \mathrm{~m}$ high in the municipality of Compostela, Nayarit; The first one located in the community of Lima de Abajo located at $21^{\circ} 06^{\prime} 02^{\prime \prime} \mathrm{N}$ and $105^{\circ} 12 ` 45^{\prime \prime} \mathrm{W}$ during September to November 2018, and the second in the community of "El Capomo" located at $21^{\circ} 21^{\prime} 09^{\prime \prime} \mathrm{N}$ and $104^{\circ} 05^{\circ} 57^{\prime \prime} \mathrm{W}$ during July to August 2019.The samples obtained from "Lima de Abajo" were hermetically transferred to the Agricultural Parasitology Laboratory of the Multidisciplinary Center for Scientific Research (CEMIC 03) of the Autonomous University of Nayarit. In the community of 'El Capomo', data collection was carried out directly in the field. Insect specimens were preserved in $70 \%$ alcohol for identification with the help of stereoscopic and compound microscopes, both of the VELAB ${ }^{\circ}$ and Labomed ${ }^{\circledR}$ brand, as well as Miller's taxonomic keys (1999). Confirmation of the species was carried out by specialists from the Entomology and Phytopathology Laboratory of the University of Nuevo León (UANL).The products evaluated were INTER-A-CH-C (Allium sativum, Capsicum frutescens, Cinnamomum zyelanicum) (International Química de Copper SA de CV), Ara3 (Ricinus communis, Azadirachta indica, Argemone mexicana) (Proan, Mexico), Evolution (Allium sativum, Quillaja saponaria) (Terra Nova, Mexico), detergent (Blanca Nieves ${ }^{\circ}$ ) (linear anionic surfactant, silicate, carbonate, sulfate and tripolyphosphate) + Cloralex $^{\bullet}$ (sodium hypochlorite) (Alen de México), imidacloprid (Sifatec, Mexico), and a combination of Habanero Chile (Capsicum chinense) + garlic (Allium sativum) + onion (Allium cepa) + wormwood (Artemisia absinthium). Extract formulation for 'Lima de Abajo': $100 \mathrm{~g}$ of $C$. chinense, $100 \mathrm{~g}$ of A. cepa, $100 \mathrm{~g}$ of A. sativum, $150 \mathrm{~g}$ of leaves and flowers of A. absinthium, 2 liters of water, $20 \mathrm{~g}$ of detergent (Blanca nieves ${ }^{\odot}$ ), dissolved in 10 liters of water.Formula adjusted for 'El Capomo': $200 \mathrm{~g}$ of C. chinense, $200 \mathrm{~g}$ of A. cepa, $200 \mathrm{~g}$ of A. sativum, $100 \mathrm{~g}$ of leaves and flowers of $A$. absinthium, 2 liters of water, $20 \mathrm{~g}$ of detergent (Blanca nieves ${ }^{\otimes}$ ), dissolved in 10 liters of water.Chile habanero, wormwood, garlic and onion were poured into a blender (Osterizer ${ }^{\circ}$ ) to obtain only the liquid, the pulp was subsequently discarded. The detergent treatment $\left(\right.$ Blanca Nieves $\left.{ }^{\circ}\right)+$ chlorine $\left(\right.$ Cloralex $\left.^{\circ}\right)$ included in this research 
as a famers control, is a product commonly used by the farmer. The mortality in the treatment water was used as a control for this calculation. The treatments evaluated were the products or mixtures of products described in (Table 1). Which were previously mixed in a volume of three liters of water, which was later applied between 8 and 9 in the morning evenly covering foliage and fruits.

The variables evaluated corresponded to the average mealybugs in each treatment before and after the application: The average population of $M$. hirsutus present was determined by the quantification of nymphs and adult females, where four young shoots of five $\mathrm{cm}$ in length per tree were collected. The formula used to calculate the percentage of effectiveness after the application of the treatments was that described by Henderson \& Tilton (1955): \% of effectiveness $=100 \times(1-(\mathrm{Ca} * \mathrm{~T} \mathrm{~d}) /(\mathrm{Cd} * \mathrm{~T} \mathrm{a})$, where: $\mathrm{Td}=$ number of $M$. hirsutus after application $\mathrm{Ta}=$ number of $M$. hirsutus before application $\mathrm{Cd}=$ number of $M$. hirsutus in the control after application $\mathrm{Ca}=$ number of $M$. hirsutus in the control before application. The design of the experiment was completely randomized with five repetitions, where each repetition was a tree and from each tree four terminal (young) shoots of five $\mathrm{cm}$ in length was evaluated. The data were analyzed by means of the analysis of variance with the general linear model to determine the differences between the treatments and later, the comparison of the mean by means of the Tukey test $(\mathrm{P}<0.05)$. All statistical analyzes were performed with Statistix version 10 software.

Table 1. Products and doses used for the management of M. hirsutus.

\begin{tabular}{ccc}
\hline Trat & Products & Dose \\
\hline T1 & Ara 3 & $10 \mathrm{~mL} / \mathrm{L}$ \\
T2 & INTER-A-CH-C & $10 \mathrm{~mL} / \mathrm{L}$ \\
T3 & Evolution & $15 \mathrm{~mL} / \mathrm{L}$ \\
T4 & Chile habanero-Onion-Wormwood-Garlic & $100 \mathrm{~mL} / \mathrm{L}$ \\
T5 & Absolute control (water) & $3 \mathrm{~L}$ \\
T6 & Farmers control (Blanca Nieves $\left.{ }^{\circ}\right)+$ Cloralex $^{\oplus}$ & $2.5 \mathrm{~mL} / \mathrm{L}$ \\
T7 & Imidacloprid & $2.5 \mathrm{~mL} / \mathrm{L}$ \\
\hline
\end{tabular}

\section{Results and discussion}

\subsection{Evaluation of organic and inorganic products 2018}

The effectiveness of the seven treatments was evaluated against the mealybug species morphologically identified as M. hirsutus. The mealybug host used in this study was the soursop orchard in open field conditions. According to the results (Table 2), an initial population was registered in the experimental area, which ranged between (11.4) and (15.25) M. hirsutus per young shoots, without presenting statistical differences prior to the application of the treatments. At 7 and 14 days after application, statistical differences were observed between treatments.

The lowest population of $M$. hirsutus was recorded in the farmers control with a value of (5.05) and (0.25) M. hirsutus per young shoots, which was significantly lower than other treatments. The maximum population of $M$. hirsutus was observed in T4 (Chile Habanero + Wormwood + Onion + Garlic) (13.25) and (10.05) at 7 and 14 days respectively. At 21 days after application, significant differences were observed between treatments, the lowest population of $M$. hirsutus was recorded in Ara 3 (2.45) and the highest population was observed in the absolute control (10.05).

At 28 days after application, the highest average was obtained in $\mathrm{T} 5$ without significant differences with $\mathrm{T} 2$ and with significant differences with respect to the other treatments. The information suggests that at 21 and 28 days after the application Ara 3 was significantly superior in the suppression of the population of M. hirsutus in the soursop orchard.

The results in Figure 1, indicated that the absolute control obtained an efficiency of $0 \%$ compared to the other treatments. Data after 7 days of application, revealed that the farmers control significantly reduced the amount of $M$. hirsutus $(56.24 \%)$ followed by INTER-A-CH-C (26.18\%), Ara3 (14.14\%), Evolution (14.04\%). The lowest reduction was caused by Imidacloprid (6.14\%) followed by (Chile habanero + Garlic + onion + wormwood) that had no effect on the population of M. hirsutus. These results differ from those found by Gowda et al. (2013), who revealed that Imidacloprid recorded a mortality of $(65.76 \%), 7$ days

Table 2. Effectiveness of products before and after the application in the "Lima de Abajo" community.

\begin{tabular}{|c|c|c|c|c|c|c|}
\hline \multirow{3}{*}{ TRT } & \multirow{3}{*}{ Products } & \multicolumn{5}{|c|}{ Average mealybug population/treatment } \\
\hline & & \multirow{2}{*}{$\begin{array}{c}\text { BA } \\
\text { T0 }\end{array}$} & \multicolumn{4}{|c|}{ DAA } \\
\hline & & & $\mathrm{T}+7$ & $\mathrm{~T}+14$ & $\mathrm{~T}+21$ & $\mathrm{~T}+28$ \\
\hline $\mathrm{T} 2$ & INTER-A-CH-C & $15.25 \mathrm{a}$ & $10.35 \mathrm{a}$ & $6.6 \mathrm{abc}$ & $4.6 \mathrm{ab}$ & $3.8 \mathrm{ab}$ \\
\hline T3 & Evolution & $12.4 \mathrm{a}$ & $9.8 \mathrm{ab}$ & $5.4 \mathrm{bcd}$ & $8.7 \mathrm{ab}$ & $0.45 b$ \\
\hline T5 & Absolute control (water) & $11.8 \mathrm{a}$ & $10.85 \mathrm{a}$ & $10.05 \mathrm{ab}$ & $10.3 \mathrm{a}$ & $8.5 \mathrm{a}$ \\
\hline T6 & Farmers control (Blanca Nieves ${ }^{\circledast}$ mas Cloralex ${ }^{\circledast}$ ) & $12.55 \mathrm{a}$ & $5.05 b$ & $0.25 \mathrm{~d}$ & $3.4 \mathrm{~b}$ & $0.7 \mathrm{~b}$ \\
\hline $\mathrm{T} 7$ & Mos blanc (Imidacloprid) & $14.6 \mathrm{a}$ & $12.6 \mathrm{a}$ & $6.5 \mathrm{abc}$ & $2.8 \mathrm{~b}$ & $0.55 b$ \\
\hline
\end{tabular}

TRT-Treatment; BA-Before application; DAA-Days After application. The means separated by the same letter between columns mean that there is no significant difference between treatments according to the Tukey test at $(\mathrm{P}>0.05)$. 


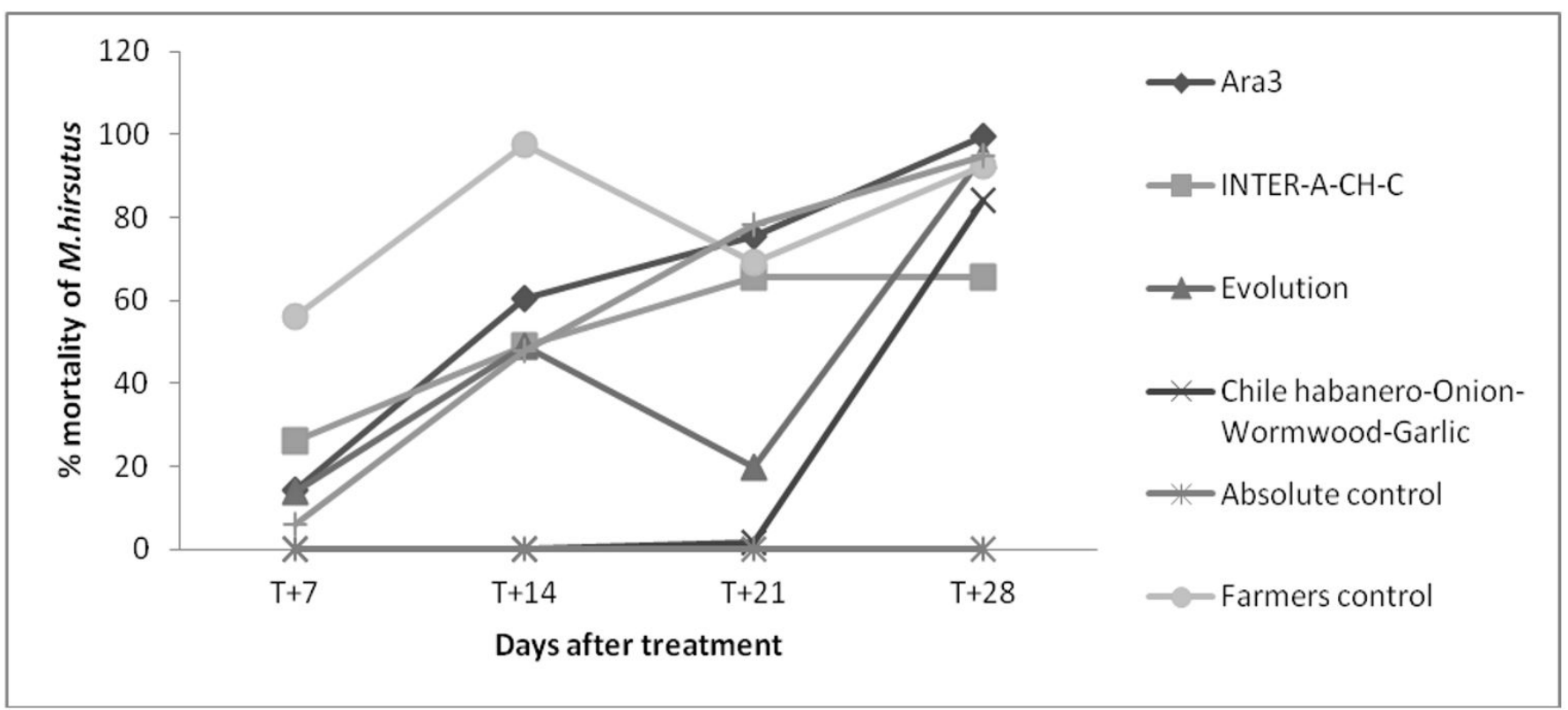

Figure 1. Percentage of effectiveness after the application of products for the control of $M$. hirsutus were between 6.14 and $99.39 \%$ in the community of "Lima de Abajo".

after application against $P$. marginatus in papaya and differ from the results by Samman et al. (2016), who reported that Imidacloprid obtained (84.21\%) mortality against M. hirsutus 72 hours after application.

The data taken after 14 days of application showed that the farmers control caused the greatest reduction (97.67\%) followed by Ara3, INTER-A-CH-C, Evolution, Imidacloprid 60.34, 49.19, 48.87 and $47.73 \%$ respectively however the combination treatment (Chile Habanero + Garlic + onion + wormwood) had no effect on the population of M. hirsutus. Castillo et al. (2018), reported that Imidacloprid was the most effective treatment with a control of (33\%) against whitefly in melon cultivation.

Regarding the overall efficacy of the 21-day treatments, the data revealed that Imidacloprid, Ara 3, farmers control and INTER-A-CH-C maintain the highest reduction 78.03, $75.38,68.96$ and $65.44 \%$ respectively, followed by Evolution and (Habanero Chile + garlic + onion + wormwood) with (19.62\%) and (1.6\%). Similar results by El-Zahi et al. (2016) indicated that imidacloprid effectively controlled the cotton mealybug, registering an average decrease of (89.2\%), in populations compared to the untreated control.

It can be seen that all the products used showed an efficiency greater than $65 \%$ at 28 days of application, the products that obtained the most efficiency were Ara 3 (99.39\%), Evolution (94.96\%), Imidacloprid (94.77\%), regional control (92.26\%), (Habanero Chile + Garlic + Onion + Wormwood) $(84.26 \%)$ and INTER-A-CH-C (65.4\%).

\subsection{Evaluation of organic and inorganic products 2019}

Table 3 shows the results of the average population of M.hirsutus. The initial mean population was 4.8 to 8.25 mealybug per young shoot / treatment, which showed no significant differences. The average population of $M$. hirsutus at 7 days after application was reduced with a significant difference between treatment 1 and 2 .

The lowest average population was recorded in Ara 3, with 0.15 mealybug per young shoot. The products in decreasing order of effectiveness were T1 $>$ T7 $>$ T6 $>$ T3 $>$ T4 $>$ T5 $>$ T2 . At 14, 21 and 28 days no statistical differences were observed between treatments (Table 3) although a decrease in M. hirsutus was observed during the three weeks. The highest mean reduction of $M$. hirsutus at 14, 21 and 28 days was Ara 3 (0.15), Evolution $(0.2)$ and Imidacloprid (0.05) respectively. Based on the results, Ara 3 and Evolution can be considered one of the best options as an alternative to insecticides.

Figure 2 Reveals that all products in this trial, except the absolute control, showed a level of effectiveness between 7.6 and $97.88 \%$. Ara 3, Imidaclorpid and Evolution showed the most control compared to INTER-A.CH-C, which was least effective during the four weeks of applications. The increase in effectiveness for (Chile habanero + garlic + onion + wormwood) can be attributed to the increase in the extract concentration used in this trial. With the adjusted dosage of garlic, Chile habanero, wormwood and onion, you can reach a level of effectiveness of M. hirsutus similar to other products in this trial.

The treatments with active ingredients based on Allium sativum, Capsicum chinense and Capsicum frutescens work as a repellent and inhibit insect ingestion, in the same way Vindas (2011) explained that Chile extract, rich in capsicin, affects the digestion system of insects. In this regard Vásquez (2000) mentions that the garlic smell changes the natural smell that each plant produces, which deceives insects because it causes an alteration and confusion due to the thiosulfates that garlic contains.

It was discovered that Ara 3 is the most effective treatment after day 7 of application with maximum suppression (96.23\%) followed by Imidacloprid, Evolution, regional control, (Chile 
Table 3. Effectiveness of products before and after application, in the community of "El Capomo".

\begin{tabular}{|c|c|c|c|c|c|c|}
\hline \multirow{3}{*}{ TRT } & \multirow{3}{*}{ Products } & \multicolumn{5}{|c|}{ Average mealybug population/treatment } \\
\hline & & \multirow{2}{*}{$\begin{array}{l}\text { BA } \\
\text { T0 }\end{array}$} & \multicolumn{4}{|c|}{ DAA } \\
\hline & & & $\mathrm{T}+7$ & $\mathrm{~T}+14$ & $\mathrm{~T}+21$ & $\mathrm{~T}+28$ \\
\hline $\mathrm{T} 2$ & INTER-A-CH-C & $5.8 \mathrm{a}$ & $4.45 \mathrm{a}$ & $2.8 \mathrm{a}$ & $2.25 \mathrm{a}$ & $0.65 \mathrm{a}$ \\
\hline $\mathrm{T} 3$ & Evolution & $8.25 \mathrm{a}$ & $1.8 \mathrm{ab}$ & $2 \mathrm{a}$ & $0.2 \mathrm{a}$ & $0.15 \mathrm{a}$ \\
\hline T5 & Absolute control (water) & $3.55 \mathrm{a}$ & $2.95 \mathrm{ab}$ & $3.1 \mathrm{a}$ & $2.3 \mathrm{a}$ & $1.3 \mathrm{a}$ \\
\hline T6 & Farmers control (Blanca Nieves ${ }^{\circledR}$ mas Cloralex ${ }^{\bowtie}$ ) & $5.7 \mathrm{a}$ & $1.7 \mathrm{ab}$ & $2.1 \mathrm{a}$ & $0.8 \mathrm{a}$ & $1.15 \mathrm{a}$ \\
\hline T7 & Mos blanc (Imidacloprid) & $6.45 \mathrm{a}$ & $1.1 \mathrm{ab}$ & $0.85 \mathrm{a}$ & $1 \mathrm{a}$ & $0.05 \mathrm{a}$ \\
\hline
\end{tabular}

TRT-Treatment; BA-Before application; DAA-Days After application. The means separated by the same letter between columns mean that there is no significant difference between treatments according to the Tukey test at $(\mathrm{P}>0.05)$.

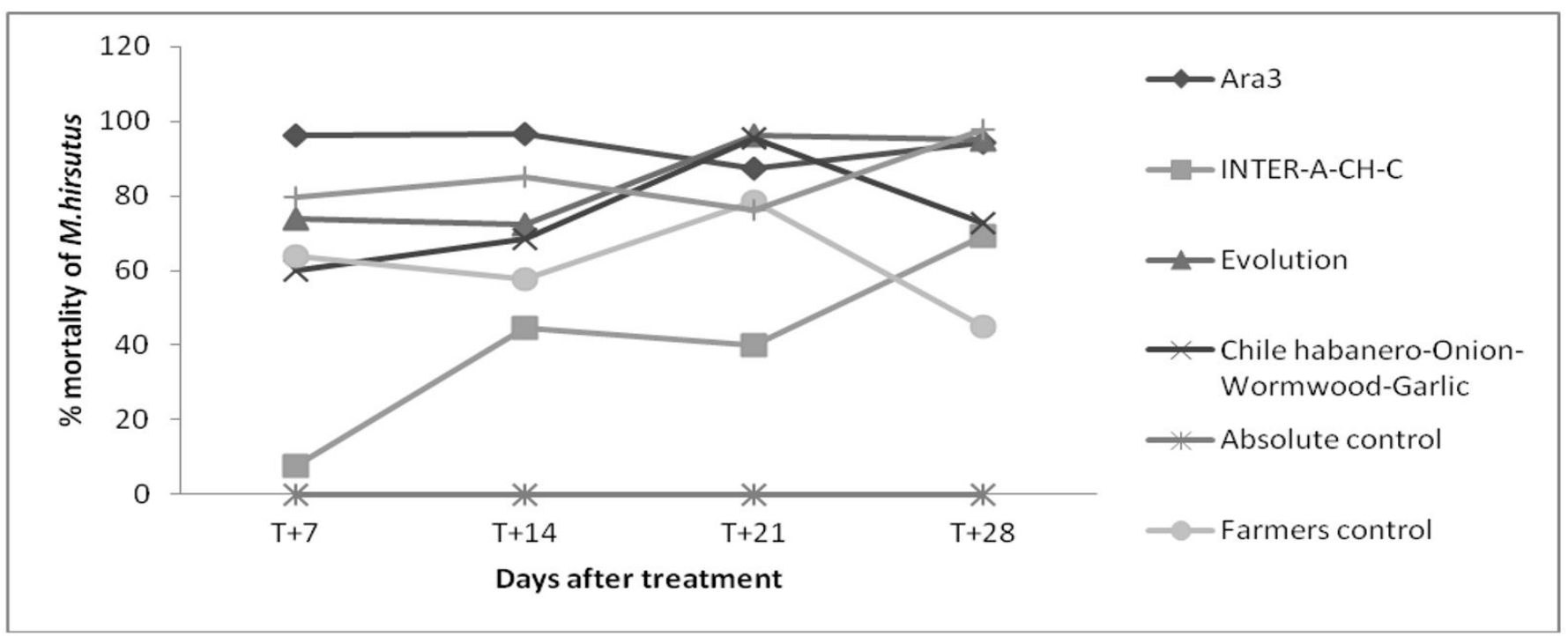

Figure 2. Percentage of effectiveness after the application of products for the control of $M$. hirsutus were between 7.6 and $97.88 \%$ in the community of "El Capomo".

habanero + Garlic + onion + wormwood) and INTER-A-CH-C with $79.47,73.74,64,60.19$ and $7.6 \%$, respectively. However, Domínguez (2013) mentioned that the combination of garlic, Chile habanero, onion and aloe as an organic extract obtained control of up to $90 \%$ against $M$. hirsutus in tulip plants with the help of cultural control (pruning). After day 14, the results showed a mortality rate of $96.42,84.91,72.24,68.29$, 57.81 and $44.72 \%$ for Ara 3, Imidacloprid, Evolution, (Chile habanero + garlic + onion + wormwood), farmers control and INTER-A-CH- C respectively.

The results obtained by Pérez et al. (2013) revealed that Ricinus communis extracts resulted in 63\% mortality of $A$. tuberculars and $41.5 \%$ after the first application in mango. After 21 days, the results revealed that Evolution (96.26\%) and (Chile habanero + Garlic + onion + wormwood) (95.25\%) had their highest reduction peak compared to Ara 3, regional control, Imidacloprid and INTER-A- CH-C with efficiency of 87.14, 78.34, 76.07 and $40.12 \%$ respectively. These results are consistent with those recorded by Romero (2017) revealed that garlic and onion extract showed $96.45 \%$ efficacy in Rambután against mealybug.

In this trial, it can be seen that all the products used have an efficacy of more than $44.9 \%$ after 28 days of application, Imidacloprid (97.88\%), Evolution (95.04\%) and Ara 3 (94.31\%) showed an efficacy greater than $94 \%$ compared to (Chile habanero + garlic + onion + wormwood) $(72.69 \%)$, INTER-A-CH-C $(69.39 \%)$ and farmer control (44.9\%), which was less than $72 \%$.

\section{Conclusions}

As an ecological alternative, Ara 3 ( $R$. communis, A. indica, A. mexicana) and Evolution (Allium sativum, Quillaja saponaria) were the most effective products to suppress the incidence of $M$. hirsutus on soursop trees in both location.

In the communities of "Lima de Abajo" and "El Capomo" Ara 3, Evolution and Imidaclorpid recorded the highest percentage of suppression and showed the lowest number of living individuals of $M$. hirsutus, 28 days after application. 


\section{References}

Amariz, A., Lima, M. A. C., \& Alves, R. E. (2018). Quality and antioxidant potential of byproducts from refining of fruit pulp. Food Science and Technology, 8(2), 203-209. https://doi.org/10.1590/fst.25816.

Castillo, J. C., Arrieta, A. R., Moya, K. V., Villalobos, S. H., \& Rodríguez, O. A. (2018). Evaluación de tres extractos naturales contra Bemisia tabaci en el cultivo del melón, puntarenas, Costa Rica. Agronomía Costarricense, 42(2), 93-106. http://dx.doi.org/10.15517/rac.v42i2.33781.

Cham, A. K., Luna-Esquivel, G., Robles-Bermúdez, A., Ríos-Velasco, C., Coronado-Blanco, J. M., \& Cambero-Campos, O. J. (2019). Insects associated with the soursop (Annona muricata L.) Crop in Nayarit, Mexico. The Florida Entomologist, 102(2), 359-365. http://dx.doi. org/10.1653/024.102.0211.

Comisión Federal para la Protección contra Riesgos Sanitarios COFEPRIS. (2018). Consulta de Registros Sanitarios de Plaguicidas, Nutrientes Vegetales y LMR. Retrieved from http://siipris03.cofepris. gob.mx/Resoluciones/Consultas/ConWebRegPlaguicida.asp/

Domínguez, B. V. (2013). Control de la cochinilla rosada del hibisco (Maconellicoccus hirsutus Green) en tulipán (Hibiscus) mediante un extracto orgánico (pp. 33-43). México, Quintana Roo: Instituto tecnológico de la zona maya.

El-Zahi, S., Aref, S. A. E.-S., \& Korish, S. K. M. (2016). The cotton mealybug, Phenacoccus solenopsis Tinsley (Hemiptera: Pseudococcidae) as a new menace to cotton in Egypt and its chemical control. Journal of Plant Protection Research, 56(2), 113-115. http://dx.doi.org/10.1515/ jppr-2016-0017.

Food and Agriculture Organization - FAO. (2012). Código internacional de conducta para la distribución y utilización de plaguicidas. Directrices sobre la prevención y manejo de la resistencia a los plaguicidas. Rome: FAO. Retrieved from http://www.fao.org/fileadmin/templates/agphome/ documents/Pests_Pesticides/Code/Annotated_Guidelines_SP.pdf

Gowda, G. B., Kumar, L. V., Jagadish, K. S., Kandakoor, S. B., \& Rani, A. T. (2013). Efficacy of insecticides against papaya mealybug, Paracoccus marginatus Williams and Granara de Willink (Hemiptera: Pseudococcidae). Current Biotica, 7(3), 161-173.

Guimarães, J. T., Silva, E. K., Ranadheera, C. S., Moraes, J., Raices, R. S. L., Silva, M. C., Ferreira, M. S., Freitas, M. Q., Meireles, M. A. A., \& Cruz, A. G. (2019). Effect of high-intensity ultrasound on the nutritional profile and volatile compounds of a prebiotic soursop whey beverage. Ultrasonics Sonochemistry, 55, 157-164. http://dx.doi. org/10.1016/j.ultsonch.2019.02.025. PMid:30853535.

Henderson, C. F., \& Tilton, E. W. (1955). Test with acaricides against the brow wheat mite. Journal of Economic Entomology, 48(2), 157161. http://dx.doi.org/10.1093/jee/48.2.157.

Hernández, F. L. M., Bautista, M. M., Carrillo, S. J. L., Sánchez, A. H., Urías, L. M. A., \& Salas, A. M. D. (2008). Control del barrenador de las semillas, Bephratelloides cubensis Ashmead (Hymenoptera: Eurytomidae) en guanábana Annona muricata L. (Annonales: Annonaceae). Acta Zoológica Mexicana, 24(1), 199-206. http:// dx.doi.org/10.21829/azm.2008.241631.

Hernández, F. L. M., Gómez, J. R., \& Andrés, A. J. (2013). Importancia, plagas insectiles y enfermedades fungosas del cultivo de guanábano (pp. 1-33). Nayarit, México: Campo Experimental Santiago Ixcuintla.

Kondo, D. T., López-Bermudez, R., \& Quintero, E. M. (2010). Manejo integrado de insectos escama (Hemiptera: Coccoidea) con énfasis en control biológico. Novedades Técnicas, 7-14.

México. Secretaría de Agricultura, Ganadería, Desarrollo Rural, Pesca y Alimentación - SAGARPA. (2014). Manual Técnico-Operativo del manejo de la Cochinilla Rosada del Hibisco Maconellicoccus hirsutus (Green) (pp. 36). México: SAGARPA.
Nascimento, M. M., Jesus, R. M., Santos, H. M., Silva, A. L. S. Jr., Campos, N. M. C. O., Silva, E. G. P., \& Lôbo, I. P. (2020). Quality pattern evaluation of frozen soursop pulps: an assessment based on chemical composition and chemometric analysis. Food Science and Technology (Campinas), 40(2), 508-516. http://dx.doi.org/10.1590/ fst.04919.

Orozco, S. M., López, P. J., Farías, L. J., \& Arenas, V. M. (1998). Sustentabilidad en el manejo de plagas y enfermedades de cultivos agrícolas. Revista Mexicana de Fitopatología, 16(1), 46-54.

Pérez, S. J., Ángel-Ríos, D. M., Arteaga, D. A., Hernández, C. E., \& Damián, N. A. (2013). Hongos entomopatogenos y extractos vegetales contra escama blanca (Aulacaspis tubercularis NEWSTEAD), en cultivo de mango en San Luis la Loma, municipio de Tecpan de Galeana, gro. México. Entomología Mexicana, 12(1), 452-455. Retrieved from http://www.entomologia.socmexent.org/revista/2013/CB/452-455.pdf

Pimentel, D., \& Levitan, L. (1986). Pesticides: amounts applied and amounts reaching pests. BioScience, 36(2), 86-91.

Pimentel, D., Mc Laughlin, L., Zepp, A., Lakitan, B., Kraus, T., Kleinman, P., Vancini, F., Roach, W. J., Graap, E., Keeton, W. S., \& Selig, G. (1993). Environment and economic effects of reducing pesticide use in agriculture. Agriculture, Ecosystems \& Environment, 46(1-4), 273-288. https://doi.org/10.1016/0167-8809(93)90030-S.

Riley, D. G., \& King, E. G. (1994). Biology and management of pepper weevil Anthonomus eugenii Cano (Coleoptera: Curculionidae): a review. Trends Agricultural Science, 2, 109-121.

Rivero, M. A. M. (2007). La cochinilla rosada del hibisco, Maconellicoccus hirsutus (GREEN), Un peligro potencial para la agricultura cubana. Rev. Protección, 22(3), 167-175.

Romero, P. M. J. (2017). Efecto de productos químicos y orgánicos para el control de cochinilla harinosa (Dysmicoccus brevipes, Pseudococcidae) en rambután, nuevo progreso, San Marcos (pp. 29-30). Guatemala: Universidad San Rafael Landivar.

Samman, F., Mubashar, H., Muhammad, F. M., Nadia, N., Noor, A., \& Zaheer, A. (2016). Field efficacy of some insecticides against hibiscus mealybug, Maconellicoccus hirsutus (Hemiptera: Pseudococcidae). Journal of Entomology and Zoology Studies, 4(1), 240-244.

Servicio de Información Agroalimentaria y Pesquera - SIAP. (2010). Anuario Estadístico de la Producción Agrícola. Retrieved from http:// www.siap.gob.mx/cierre-de-la-produccion-agricola-porestado/

Servicio de Información Agroalimentaria y Pesquera - SIAP. (2018). Anuario Estadístico de la Producción Agrícola. Retrieved from http:// www.siap.gob.mx/cierre-de-la-produccion-agricola-porestado/

Servicio Nacional de Sanidad, Inocuidad y Calidad Agroalimentaria SENASICA. (2014). Laboratorio regional de producción de agentes de control biológico. México: SENASICA. Retrieved from http:// www.senasica.gob.mx/

Servicio Nacional de Sanidad, Inocuidad y Calidad Agroalimentaria SENASICA. (2019). Cochinilla rosada del hibisco (Maconellicoccus hirsutus) Green, 1908 (Ficha técnica, No. 6, pp. 22). México: SENASICA.

Servín, R., García, H. J. L., \& Troyo, D. E. (2007). Buenas prácticas en el manejo plagas para una agricultura, ganadería y producción forrajera sostenible en zonas áridas (pp. 85). La Paz, México: Editorial Centro de Investigaciones Biológicas del Noroeste.

Vásquez, A. O. L. (2000). Manejo de cochinilla (Dysmicoccus brevipes) en el cultivo de piña orgánica en la zona del Lago de Yojoa, Honduras.

Vindas, A. M. (2011). Evaluación de productos naturales para el control de la cochinilla harinosa, (Dysmicoccus brevipes Cockerell) (Hemiptera: Pseudococcidae), en el fruto de pina, San Carlos (Tesis de maestría). Universidad de Costa Rica, San Carlos, Costa Rica. 